\title{
PENINGKATAN KUALITAS MOTORIK ANAK MELALUI PENDIDIKAN ANAK USIA DINI BERBASIS ALAT PERMAINAN EDUKATIF DI POS PAUD PELANGI KELURAHAN MERGOSONO KECAMATAN KEDUNGKANDANG MALANG
}

\author{
Baroroh Lestari, Pudji Herijanto, Ellyn Eka W., Heru Utomo, Diana Eka P. \\ barorohlestari@gmail.com
}

\begin{abstract}
Early childhood education is a form of education that focuses on laying the foundation for physical growth and development (fine and gross motor intelligence), intelligence (power of thought, creativity, motivational intelligence, spiritual intelligence), social emotions (emotions and motivation ) and religion), language and communication in accordance with the uniqueness of PAUD. The existence of Pos PAUD in the Mergosono Subdistrict of Kedungkandang District Malang City is one of the forms and efforts to bridge the need for early education services at the Subdistrict level which is intended for the community, which provides assistance for more intensive formal PAUD. The target in this activity is Pos PAUD Mergosono, Kedungkandang District, Malang. Community dedication activities in PAUD Pelangi in Mergosono Sub-District, Kedungkandang District, Malang City are very beneficial for partners, especially in improving the quality of learning. Thus, teaching and learning activities will be more interesting and children will have the opportunity to develop their potential, which in turn will also improve children's motor skills. The activities that have been carried out in community dedication are aimed at increasing APE equipment and lockers to store them. While for managers, training on management and administration of PAUD managers is given. Based on the results of the implementation of the service that has been done can ask for advice: 1) The existence of follow-up activities that contain special training so that it can improve the ability of teachers to carry out teaching and learning. 2) APE procurement needs to be done to improve children's motor skills.
\end{abstract}

Kata kunci: PAUD, APE, Motoric.

\section{PENDAHULUAN}

\subsection{Latar Belakang}

Anak usia dini adalah anak yang sedang berada pada rentang usia 4-6 tahun dan tergolong kedalam masa perkembangan. Montessori (Hurlock: 2013) berpendapat bahwa usia 3-6 tahun merupakan periode sensitive atau masa peka pada anak, yaitu suatu periode dimana fungsi tertentu perlu dirangsang, diarahkan sehingga tidak terhambat perkembangannya. Masa ini juga mencakup sensitivitas terhadap keteraturan lingkungan, mengeksplorasi lingkungan dengan lidah dan tangan, berjalan, sensitivitas terhadap objek yang kecil dan detail serta terhadap aspek-aspek sosial kehidupan.
Di Indonesia usia dini disepakati usia antara 0-6 tahun yang dijelaskan pada pasal 28 Undang-Undang Sistem Pendidikan Nasional no. 20 tahun 2003 ayat 1 dijelaskan bahwa "anak usia dini adalah anak yang masuk dalam rentang usia 0-6 tahun". Dari penjelasan tersebut dapat dipahami bahwa anak usia dini adalah anak yang berkisar antara 0-6 tahun yang memiliki pertumbuhan dan perkembangan sesuai dengan karakteristiknya. Pendidikan anak usia dini merupakan salah satu bentuk penyelenggaraan pendidikan yang menitikberatkan pada peletakan dasar ke arah pertumbuhan dan perkembangan fisik (koordinasi motorik halus dan kasar), kecerdasan (daya pikir, daya cipta, kecerdasan emosi, kecerdasan spiritual), social emosional (sikap dan perilaku serta beragama), bahasa dan komunikasi sesuai dengan keunikan tahap-tahap perkembangan yang dilalui oleh anak usia dini.

Pendidikan anak usia dini (PAUD) merupakan upaya yang dilakukan dalam menciptakan tunas-tunas bangsa yang berkualitas serta siap untuk bersaing dalam arus perkembangan jaman. Pendidikan anak usia dini merupakan investasi yang sangat berharga bagi bangsa, karena anak-anak usia dini merupakan generasi penerus bangsa. Disebutkan dalam Undangundang Republik Indonesia No. 23 tahun 2003 tentang Sistem Pendidikan Nasional, pasal 1, ayat 14 (Depdiknas, 2008b:1) bahwa

Kondisi inilah yang memungkinkan munculnya Pos PAUD. Keberadaan pos PAUD di wilayah Kelurahan Mergosono Kecamatan Kedungkandang Kota Malang merupakan salah satu bentuk dan upaya untuk menjembatani kebutuhan layanan Pendidikan usia dini ditingkat kelurahan. Pos PAUD ini berada di setiap RW. Pos PAUD yang ada di wilayah Kelurahan Mergosono, diperuntukkan bagi masyarakat sekitar yang belum siap mengikutsertakan anaknya dalam PAUD formal yang lebih intensif.

\section{KAJIAN TEORI}

\subsection{Pendidikan anak usia dini}

Pendidikan anak usia dini adalah jenjang pendidikan sebelum pendidikan dasar yang merupakan suatu upaya pembinaan yang ditujukan bagi anak sejak lahir sampai dengan usia enam tahun. Pendidikan ini dilakukan melalui pemberian rangsangan pendidikan untuk membantu pertumbuhan memasuki pendidikan lebih lanjut, yang diselenggarakan pada jalur formal, nonformal, dan informal (Hasan, 2012).

Salah satu tokoh pendidikan anak usia dini, Montessori (2013) mendifinisikan pendidikan anak usia dini sebagai sebuah proses dinamis dimana anakanak berkembang menurut ketentuan-ketentuan dalam dari kehidupan mereka, dengan kerja sukarela mereka 
ketika ditempatkan dalam sebuah lingkungan yang disiapkan untuk memberi mereka kebebasan dalam ekspresi diri. Lebih lanjut, Suyadi (2013) memberikan pengertian tentang pendidikan anak usia dini sebagai salah satu bentuk penyelenggaraan pendidikan yang menitikberatkan pada peletakan dasar ke arah pertumbuhan dan perkembangan fisik (koordinasi motorik halus dan kasar), kecerdasan (daya pikir, daya cipta, kecerdasan emosi, kecerdasan spiritual), sosio emosional (sikap dan perilaku serta agama) bahasa dan komunikasi, sesuai dengan keunikan dan tahap-tahap perkembangan yang dilalui oleh anak usia dini (Suyadi, 2013).

\subsection{Prinsip-prinsip Pendidikan Anak Usia Dini}

Prinsip-prinsip Pendidikan anak usia dini dibedakan menjadi prinsip-prinsip teoritis dan prinsipprinsip praktis. Suyadi (2013) mengutip pendapat Tina Bruce yang telah merangkum sepuluh prinsip teoritis pendidikan anak usia dini sebagai berikut:

1. Masa kanak-kanak adalah dari kehidupannya secara keseluruhan. Masa ini bukan dipersiapkan untuk mengadapi kehidupan pada masa uang akan datang, melainkana sebatas optimalisasi potensi secara optimal.

2. Fisik, metal, dan kesehatan, sama pentingnya dengan berpikir maupun aspek psikis (spiritual) lainnya. Oleh karena itu, keseluruhan (hilistis) aspek perkembangan anak merupakan pertimbangan yang sama pentingnya.

3. Pembelajaran pada usia dini melalui berbagai kegiatan saling berkait satu dengan yang lain sehingga pola stimulasi perkembangan anak tidak boleh sektoral dan parsial, hanya satu aspek perkembangan saja.

4. Membangkitkan motivasi intrinsik (motivasi dari dalam diri) anak akan menghasilkan inisiatif sendiri (self directed activity) yang sangat bernilai dari pada motivasi ekstrensik.

5. Program pendidikan pada anak usia dini perlu menekankan pada pentingnya sikap disiplin karena sikap tersebut dapat membentuk watak dan kepribadiannya.

6. Masa peka (usia 0-3 tahun) untuk mempelajari sesuatu pada tahap perkembangan tertentu, perlu diobservasi lebih detail.

7. Tolok ukur pembelajaran PAUD hendaknya bertumpu pada hal-hal atau kegiatan yang telah mampu dikerjakan anak, bukan mengajarkan halhal baru kepada anak, meskipun tujuannya baik karena baik menurut guru dan orang tua belum tentu baik menurut anak.

8. Suatu kondisi terbaik atau kehidupan terjadi dalam diri anak (innerlife) khususnya pada kondisi yang menunjang.

9. Orang-orang sekitar (anak dan orang dewasa) dalam interaksi merupakan sentral penting karenamerka secara otomatis menjadi guru bagi anak.

10. Pada hakikatnya, pendidikan anak usia dini merupakan interaksi antara anak, lingkungan, orang dewasa, dan pengetahuan.

\subsection{Lingkup Perkembangan Motorik Anak}

Lingkup perkembangan pada anak usia dini terdiri dari lima lingkup, yaitu nilai agama dan moral, fisik motorik, kognitif, sosial emosional dan bahasa hal tersebut dapat dilihat pada Permendikas Nomor 58 (2009) dan juga pada Kurikulum 2013 (2013). Begitu pula dijelaskan oleh Suyadi (2013) bahwa kecerdasan pada anak bukan hanya pada otaknya yang berkembang cepat tetapi bergantung pada pertumbuhan dan perkembangan pada aspek yang lain, aspek tersebut ditentukan oleh tingkat pencapaian perkembangan, aspek yang dimaksud adalah fisik motorik, bahasa, kognitif, sosial-emosional dan rasa beragama. Maka dari itu dapat disimpulkan bahwa lingkup perkembangan pada anak ada lima, yaitu fisik motorik, bahasa, kognitif, sosial emosional dan rasa beragama.

Salah satu lingkup perkembangan adalah fisik motorik, berikut ini adalah penjelasan dari lingkup perkembangan fisik motorik. Perkembangan motorik menurut Hurlock (2013), adalah perkembangan dari unsur kematangan pengendalian gerak tubuh dan otak sebagai pusat gerak. Menurut Suyadi (2013), perkembangan fisik motorik adalah perkembangan jasmaniah melalui kegiatan pusat saraf, urat saraf, dan otot yang terkoordinasi dan berasal dari perkembangan refleks dan kegiatan yang telah ada sejak lahir. Menurut Eka dkk (2008), keterampilan umum pada motorik yang biasanya dilakukan oleh anak-anak biasanya menyangkut keterampilan tangan dan kaki.

\subsection{Pengertian Manajemen}

Manajemen merupakan kata yang berasal dari Bahasa Inggris yaitu manage. Dalam kamus Bahasa Inggris dikatakan bahwa manage mempunyai arti mengatur, mengurus, melaksanakan, mengelola, (Echols dan Shadily, 2007). Sementara menurut Stoner dalam Handoko (2012) dikatakan bahwa manajemen merupakan proses perencanaan, pengorganisasian, pengarahan dan pengawasan usaha para anggota organisasi dan penggunaan sumber daya organisasi lainnya agar mencapai tujuan organisasi yang telah ditetapkan.

Dengan demikian dapat dikemukakan bahwa manajemen merupakan sebuah proses yang terdiri dari perencanaan, pengorganisasian, pengarahan dan pengawasan untuk mencapai tujuan tertentu dengan melakukan pemanfaatan sumber dayamanusia dan sumber-sumber lainnya.

\subsection{Fungsi-fungsi Manajemen}

\section{Planning (perencanaan)}

Perencanaan dapat didefinisikan sebagai penetuan terlebih dahulu apa yang harus dikerjakannya. Dalam perencanaan terlibat unsur penetuan yang berarti bahwa dalam perencanaan tersebut tersirat pengambilan keputusan. Karena itu perencanaan dapat 
dapat dilihat sebagai suatu proses dalam suatu kerangka untuk mengambil keputusan dan penyusunan rangkaian tindakan selanjutnya di masa depan. Rencana yang baik akan merumuskan tujuan dan sasaran apa yang ingin dicapai. Perencanaan adalah kumpulan keputusankeputusan. Planning adalah suatu proses untuk menetukan rencana (plan).

\section{Organizing (organisasi)}

Tujuan pengorganisasian adalah untuk mengelompokkan kegiatan sumber daya manusia dan sumber daya lainnya yang dimiliki agar pelaksanaan dari suatu rencana dapat dicapai secara efektif dan ekonomis. Menurut Handoko (2012), pengorganisasian ialah pengaturan kerja bersama sumber daya keuangan, fisik dan manusia dalam organisasi. Pengorganisasian merupakan penyusunan stuktur organisasi yang sesuai dengan tujuan organisasi, sumber daya yang dimilikinya, dan lingkungannya yang melingkupinya.

\section{Actuating (pelaksanaan)}

Masalah penggerakan berkaitan erat dengan manusia dan paling sulit dilakukan dari semua fungsi manajemen. Menggerakkan manusia merupakan hal yang paling sulit, karena manusia pekerja adalah makhluk hidup yang mempunyai harga diri. Perasaan dan tujuan yang berbeda-beda. Fungsi penggerakan ini diibaratkan sebagai kunci mobil, mobil hanya akan dapat bergerak jika kunci stater telah berfungsi. Terry dalam Handoko (2012) memberikan definisi actuating (penggerakan) adalah membuat semua anggota kelompok agar mau bekerja sama dan bekerja secara ikhlas serta bergairah untuk mencapai sesuai dengan perencanaan dan usaha-usaha pengorganisasian.

\section{Controlling (pengawasan)}

Pengawasan ialah proses pemantauan, penilaian, dan pelaporan rencana atas pencapaian tujuan yang telah ditetapkan untuk tindakan korektif guna penyempurnaan lebih lanjut.pengawasan bukan hanya untuk mencari kesalahan-kesalahan, tetapi berusaha untuk menghindari terjadinya kesalahan-kesalahan serta memperbaikinya jika terdapat kesalahankesalahan. Jadi, pengawasan dilakukan sebelum proses, saat proses, dan setelah proses, yakni hingga hasil akhir diketahui.

\section{METODE}

Sasaran dalam kegiatan Pengabdian Kepada Masyarakat (PkM) ini adalah Pos PAUD Pelangi Kelurahan Mergosono Kecamatan Kedungkandang Malang. Metode yang digunakan dalam kegiatan PkM ini adalah:

a) Alih Pengetahuan

Alih pengetahuan diberikan dengan metode penyampaian materi yang sesuai dengan bimbingan yang dilaksanakan serta dengan memberikan contoh-contoh dalam bentuk slide mengenai pengelolaan manajemen Pos PAUD dengan sistem Planning, Organizing, Actuating and Controlling (POAC) dan pemilihan APE yang terstandart untuk meningkatkan kualitas motorik anak didik Pos PAUD Pelangi.

b) Diskusi dan Tanya Jawab
Dilaksanakan untuk memberikan ruang kepada khalayak sasaran dalam memahami lebih lanjut tentang materi yang disampaikan serta membantu membangun hubungan yang lebih erat antara pelaksana PkM dan khalayak sasaran.

c) Pembahasan Masalah

Dalam kegiatan ini pelaksana PkM terlibat secara langsung membantu guru dan manajemen Pos PAUD Pelangi dalam mengelola Pos PAUD menggunakan pendekatan POAC dalam teknik menyampaikan materi penggunaan Pendekatan POAC untuk mengelola Pos PAUD, menjaga situasi tetap formal, pemilihan bahasa yang tegas, lugas tapi sopan, terutama bagaimana cara mempengaruhi guru dan manajemen Pos PAUD Pelangi namun tidak terkesan menggurui.

\section{HASIL DAN PEMBAHASAN}

\subsection{Pelaksanaan Kegiatan}

Sesuai dengan metode PKM yang dirancang pada Bab IV, maka pelaksanaan kegiatan pengabdian sebagai berikut:

1. Pelatihan Manajemen dan Administrasi Pos PAUD Pelangi

Berdasarkan hasil wawancara awal dengan pengelola Pos PAUD Pelangi, maka diperoleh informasi bahwa pihak pengelola mengalami kesulitan dalam melakukan manajemen dan administrasi Pos PAUD Pelangi. Pelatihan yang diberikan disini berkaitan dengan manajemen personalia penyelenggara Pos PAUD Pelangi yang meliputi perencanaan SDM, rekruitmen, dan administrasi personalia.

\section{a. Perencanaan Sumber Daya Manusia}

Sumber Daya Manusia (SDM) memegang peranan penting dalam sebuah organisasi. Masalah yang dihadapi manajemen sumber daya manusia saat ini adalah cepatnya perubahan yang terjadi pada bidang pemerintahan yang tentunya berdampak pada perencanaan tenaga manusia. Adapun yang dimaksud dengan proses perencanaan sumber daya manusia adalah suatu proses analisa dan simulasi kebutuhan SDM sesuai dengan data rekapitulasi kekuatan SDM yang dimiliki oleh organisasi, dikaitkan dengan rencana pengembangan aktifitas departemen dimasa mendatang.

Seorang kepala sekolah atau manajer dalam melakukan perencanaan, harus mempertimbangkan jumlah pegawai yang direcanakan, keahlian yang dibutuhkan, jenis ketrampilan macam apa yang menjadi kebutuhan dan lain sebagainya. Perencanaan yang baik adalah perencanaan yang dapat terlaksana sepenuhnya atau setidaknya mendekati seluruhnya. Oleh karena itu, perencanaan harus didasarkan pada tiga dimensi waktu, yaitu masa lampau, masa sekarang dan masa yang akan datang. 
Pada dasarnya proses perencanaan tenaga manusia terdiri dari tiga sub proses, yaitu :

1. Proses pembentukan data rekapitulasi untuk analisa dan simulasi, dimana pada prinsipnya akan diolah dari data administrasi yang dimiliki untuk mendapatkan gambaran kekuatan SDM saat ini, dan juga dari segi ketersediaan SDM tersebut.

2. Proses pengadaan sumber daya manusia/recruitment, dimana pada prinsipnya hampir sama seperti pada pengumpulan Biodata, tapi dalam ruang lingkup informasi yang lebih kecil dan diikuti oleh cara penilaian/kriteria penerimaan.

3. Proses alokasi/realokasi sumber daya manusia atau redeployment, yang mana dengan menggunakan data administrasi yang ada, dapat dianalisa informasi kebutuhan penempatan atau realokasi seorang personel ketempat yang lebih tepat.

\section{b. Rekruitmen Pegawai}

Langkah selanjutnya setelah proses perencanaan SDM adalah rekruitmen pegawai. Terdapat beberapa hal yang perlu diperhatikan dalam rekruitmen pegawai berkaitan dengan keahlian yang harus dimiliki oleh pegawai antara lain iman yang kuat, jujur, amanah, disiplin, cerdas, terampil, cekatan, mudah tanggap terhadap setiap persoalan, tanggung jawab, mempunyai rasa memiliki, dan mampu mengembangkannya. Selain itu, dalam memilih pegawai perlu juga mempertimbangkan usia yang dikaitkan dengan jenis pekerjaan.

\section{c. Administrasi Personalia}

Proses ini adalah proses yang paling dasar dalam pengumpulan informasi yang berhubungan dengan sistem kepegawaian. Dimana dalam hal ini dilakukan pengumpulan informasi yang berhubungan dengan kelengkapan atau pelengkap dari proses administrasi umum yang berhubungan dengan seorang personel.

\subsection{Pengadaan Alat Permainan Edukatif (APE)}

Pengadaan APE berupa alat-alat peraga yang berkaitan dengan angka, huruf, alat musik, kendaraan dan binatang. Dengan demikian, diharapkan peserta didik Pos PAUD Pelangi dapat mengidentifikasi dan mengenai hal-hal yang berkaitan dengan angka, huruf, alat musik, jenisjenis kendaraan dan jenis-jenis binatang. Kemudian juga berupa puzzle yang akan mengasah kemampuan motorik anak.

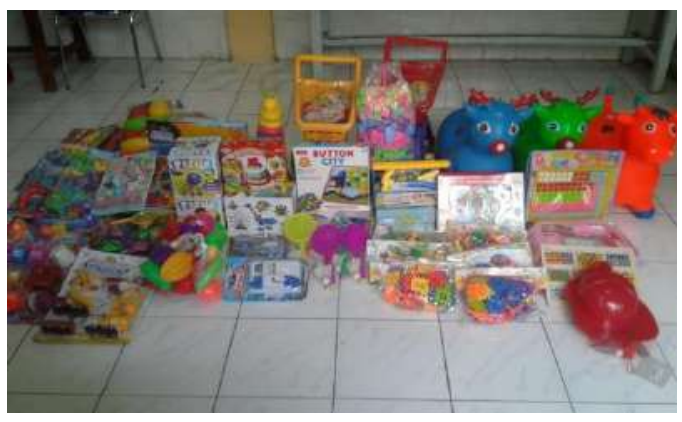

Gambar 2. Pengadaan APE

2. Pengadaan loker untuk penyimpanan APE.

Pengadaan loker penyimpanan bertujuan untuk sarana penyimpanan APE yang telah diberikan. Dengan demikian, APE dapat mudah diambil dan dirapikan kembali oleh peserta didik Pos PAUD Pelangi.

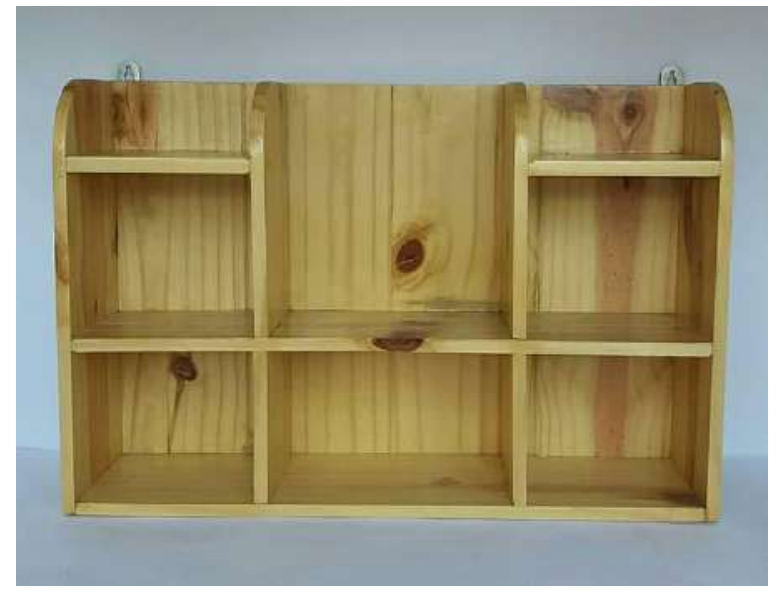

Gambar 3. Pengadaan Loker APE

\subsection{Pengadaan Buku Administrasi PAUD}

Pengadaan buku administrasi PAUD ini bertujuan untuk membantu Pos PAUD Pelangi dalam melakukan tertib administrasi. Mulai dari pencatatan surat masuk dan surat keluar. Pencatatan keuangan. Pencatatan yang berkaitan dengan personalia Pos PAUD Pelangi.

\subsection{Pembahasan}

Pelatihan Manajemen dan Administrasi Personalia bagi pengelola Pos PAUD Pelangi merupakan hasil dari diskusi awal. Berdasarkan hasil diskusi diketahui bahwa pengelola Pos Paud Pelangi mengalami kendala dalam hal manajemen dan administrasi personalia. Oleh karena itu, dilakukan pengabdian dalam bentuk pemberian materi berkaitan dengan manajemen dan administrasi Pos PAUD Pelangi,

Target peserta pelatihan manajemen dan administrasi pengelolaan Pos PAUD adalah pengelola Pos PAUD Pelangi. Dalam kegiatan ini, seluruh pengelola dapat hadir dan mengikuti kegiatan tersebut dengan baik. Materi yang disampaikan meliputi perencanaan SDM, rekruitmen, dan administrasi personalia. Ketercapaian tujuan pelatihan manajemen 
dan administrasi pengelolaan Pos PAUD serta penyediaan APE dan lemari penyimpanan APE telah tercapai dengan baik.

Ketercapaian target materi pada kegiatan pengabdian ini cukup baik, karena materi pendampingan telah dapat disampaikan secara keseluruhan. Materi yang disampaikan antara lain:

1. Perencanaan SDM

2. Rekruitmen, dan

3. Administrasi personalia.

Kemampuan peserta dalam penguasaan materi masih kurang dikarenakan waktu yang singkat dalam penyampaian materi dan kemampuan para peserta yang berbeda-beda. Hal ini disebabkan jumlah materi yang banyak hanya disampaikan dalam waktu sehari sehingga tidak cukup waktu bagi para peserta untuk memahami dan mempraktekkan secara lengkap semua materi yang diberikan.

Secara keseluruhan kegiatan pengabdian yang dilakukan di Pos PAUD Pelangi dapat dikatakan berhasil. Keberhasilan ini selain diukur dari keempat komponen di atas, juga dapat dilihat dari kepuasan peserta setelah mengikuti kegiatan dan penggunaan APE oleh peserta didk Pos PAUD Pelangi.

\subsection{Luaran yang dicapai}

Luaran dalam kegiatan pengabdian ini adalah: Artikel untuk dipublikasikan di Jurnal ilmiah berISSN.

\section{SIMPULAN DAN SARAN}

\subsection{Simpulan}

1. Kegiatan PKM pada Pos PAUD Pelangi di Kelurahan Mergosono Kecamatan Kedungkandang Kota Malang sangat memberikan manfaat untuk mitra, terutama dalam meningkatkan kualitas pembelajaran. Dengan demikian, kegiatan belajar mengajar akan semakin menarik dan anak akan memiliki kesempatan untuk mengambangkan potensi yang dimilikinya, yang pada akhirnya juga akan meningkatkan kemampuan motorik anak.

2. Kegiatan yang telah dilakukan dalam PKM ini beruoa peningkatan peralatan APE yang bersifat indoor berupa berbagai macam puzzle, pengenalan binatang, pengenalan berbagai profesi dan sebagainya. Selain iytu, kegiatan ini juga memberikan loker untuk menyimpan APE yang diberikan. Sementara untuk pengelola diberikan pelatihan tentang manajemen dan administrasi pengelola Pos PAUD.

\subsection{Saran}

Berdasarkan hasil pelaksanaan pengabdian yang telah dilakukan dapat diajukan beberapa saran sebagai berikut:

1. Waktu pelaksanaan kegiatan pengabdian perlu ditambah agar tujuan kegiatan dapat tercapai sepenuhnya, tetapi dengan konsekuensi penambahan biaya pelaksanaan. Oleh karena itu biaya PPM sebaiknya tidak sama antara beberapa tim pengusul proposal, mengingat khalayak sasaran yang berbeda pula.

2. Adanya kegiatan lanjutan yang berupa pelatihan sejenis selalu diselenggarakan secara periodik sehinga dapat meningkatkan kemampuan guru dalam melaksanakan proses belajar mengajar.

\section{DAFTAR REFERENSI}

[1]. Departemen Pendidikan Nasional. (2009). Permen 58 tahun 2009. Jakarta: Direktorat Jendral Mnajemen Pendidikan Dasar dan Menengah Pembinaan TK SD.

[2]. Departemen Pendidikan Nasional. (2013). Kurikulum 2013. Jakarta: Direktorat Jendral Manajemen Pendidikan Dasar dan Menengah Pembinaan TK SD.

[3]. Direktorat Jenderal Pendidikan Luar Sekolah. (2006). Pedoman Teknis Penyelenggaraan Kelompok Bermain. Yogyakarta: Departemen Pendidikan Nasional.

[4]. Direktorat Jenderal Pendidikan Anak Usia Dini dan Pendidikan Masyarakat. (2015). Jumlah Satuan PAUD D.I.Yogyakarta.. Diunduh pada app.pauddikmas.kemendikbud.go.id/pendataan/da podikpaudni/index.php?md=reporttp\&item=report 01a\&propid=34\&kbkot_id=3471\&kec_id=kel_id =. Jumlah Satuan PAUD D.I.Yogyakarta. Jakarta: Kementrian Pendidikan dan Kebudayaan Indonesia. 23 Februari 2018. 10.00

[5]. Echols,Jhon M dan Shadily, Hasan, (2007).kamus Inggris-Indonesia.Cetakan ke-29 Jakarta,PT Gramedia

[6]. Hurlock, Elizabeth B. (2013). Perkembangan Anak. Jakarta: Erlangga.

[7]. Hasan, Maimunah. (2012). Pendidikan Anak Usia Dini. Yogyakarta: DIVA Press.

[8]. Handoko, T. Hani (2012), Manajemen Personalia dan Sumberdaya Manusia, Yogyakarta: BPFE.

[9]. Suyadi. (2010). Psikologi Belajar Pendidikan Anak Usia Dini. Yogyakarta: Pedagogia.

[10].Muhammad Fadlillah. (2012). Desain Pembelajaran PAUD. Yogyakarta: ArRuzz Media.

[11].Hasan, Maimunah (2010) PAUD (Pendidikan Anak Usia Dini): Panduan Lengkap Manajemen Mutu Pendidikan Anak Untuk Para Guru Dan Orang Tua, Diva Press, Yogyakarta.

[12].Montessori, Maria, Gerald Lee Gutek (ed.), (2013) Metode Montessori, Terj. Ahmad Lintang Lazuardi, Pustaka Pelajar, Yogyakarta.

[13].Eka, Rita, Siti Partini, Yulia Ayriza, Hiryanto, Rosita. (2008). Perkembangan Peserta Didik. Yogyakarta: UNY Press.

[14]. Suyadi, (2013). Konsep Dasar Paud, Rosdakarya, Bandung, cet. I 